\title{
Reader-Response Criticism and Teaching Composition
}

\begin{abstract}
Are rhetoric and poetics separate and discrete fields of study? Although rhetorical theorists from Aristotle to Kenneth Burke have pointed out the overlap between these two areas, detailed discussion usually centers on showing their distinctiveness. The common ground of rhetoric and poetics is a "no man's land, the limbo of the faithless, for no self-respecting esthetician will vulgarize his subject by glancing, even momentarily, at rhetoric, and the rhetorician, though generally much more comprehensive in his viewpoint than the esthetician, is so busied with the 'practical' discourses of history (both past and present) that he seldom has time to concern himself with poetry." ${ }^{1}$ Extended entry into this no man's land is long overdue, and especially so now that English departments are becoming more aware of their dual responsibility to teach composition and promote literary study. A sharp distinction between rhetoric and poetics encourages us to view these duties as two completely separate functions. Actually, the study of literature and the teaching of writing are closely related and mutually illuminating. In fact, recent trends in literary criticism suggest that a rapprochement may be taking place between literary and composition theory; shared paradigms are now emerging. In this Appendix I will outline these developing areas of shared theory and practice, emphasizing the role of reader-response criticism as a growing bond between rhetoric and poetics.
\end{abstract}

Observation and interpretation always proceed within ac-

1. W. Ross Winterowd, "Beyond Style," Philosophy and Rhetoric, 5 (1972), 110. My enormous debt to Professor Winterowd's insights in composition theory will be evident from my many references to his work below. 
cepted paradigms, whether in physics, medical research, composition study, or literary criticism. ${ }^{2}$ Since the 1940 os, New Critical formalism has clearly served as the dominant paradigm in American criticism and theory. This "objective" approach (in its purest form, at least) viewed a literary work as an artifact, cut off from both authorial intention and reader response. It rejected "external" criticism and restricted its analysis to the work in and of itself. Many New Critics spacialized the text, viewing its parts in relation to the artistic whole, a tightly organized network of structures. This American New Criticism provided little of interest to rhetoricians. It not only ignored the audience, a central concern of rhetoric; it also actively discouraged talk about readers through its condemnation of the Affective Fallacy.

In recent years there have been many reactions against New Criticism. In one such reaction, a model of literature as communication challenges the established model of literature as aesthetic product. Those critics using this revitalized communication model practice the Intentional and Affective Fallacies with impunity. This new paradigm of criticism has much more to offer the composition teacher than did the old formalist paradigm, and it is here that we can begin to see the recent overlap of rhetoric and poetics most clearly. Two contemporary critical approaches that work within the model of literature as communication are textual-biographical and reader-response criticisms. $^{3}$

Recent textual-biographical critics view art as process, not as product. This may at first seem contradictory to our usual notion that textual editors are interested only in establishing a product, the intended text for a critical edition. But such a portrayal is incomplete. As we saw in Chapter 4, the scholarly editor establishes his text based on the "author's final intention," and

2. See Thomas S. Kuhn, The Structure of Scientific Revolutions, $2 \mathrm{~d}$ ed. (Chicago: University of Chicago Press, 197o), esp. pp. 10, 187-91. Cf. Patricia Bizzell, "Thomas Kuhn, Scientism, and English Studies," College English, 4o (1979), 764-71, and Grant Webster, The Republic of Letters (Baltimore: Johns Hopkins University Press, 1979).

3. For another vigorous advocate of the communication model for literature, see Mary Louise Pratt, Toward a Speech Act Theory of Literary Discourse (Bloomington: Indiana University Press, 1977), especially her attack on the a-contextual formalist model assumed by intrinsic criticism and structuralist theory, pp. $7^{2-75}$. 


\section{Appendix}

this criterion must be viewed not only in terms of the textualist's interpretation of the intended conventional responses but also in light of his historical knowledge of the author's whole composing process. In fact, the textualist sees the literary work itself as a process, a series of intentional acts by the author. When a critic studies a work from this textual-biographical perspective, when he practices what has been called the "New Scholarship," he revels in the Intentional Fallacy, bringing to bear his total knowledge of the author's composing process (including extant forms of the text) and the relevant biographical events that affect that process. ${ }^{4}$

From a complementary perspective, recent reader-oriented critics have also viewed art as communicative process. As $\mathbf{M}$. $\mathrm{H}$. Abrams puts it: "Since the late 1950's ... there has been a strong revival of interest in literature as a public act involving communication between author and reader, and this has led to the development of a rhetorical criticism which, without departing from a primary focus on the work as such, undertakes to analyze those elements within a poem or a prose narrative which are their primarily for the reader's sake."5 Abrams cites the work of Wayne Booth in his Rhetoric of Fiction (1961) as an example of this type of criticism. During the 1970 , reader-response critics extended (and transformed) this rhetorical approach: Wolfgang Iser in phenomenology, Jonathan Culler through his theory of reading conventions, and Stanley Fish in his affective stylistics. Whereas the textual-biographical critics view literature as a series of acts by the author, reader-response critics view it as a series of acts by the reader. Fish's criticism, for example, is "an analysis of the developing responses of the reader in relation to the words as they succeed one another in time," ${ }^{6}$ and, as we saw in Chapters 2 and 3 , this temporal reading model emphasizes the series of acts that

4. See Brian Higgins and Hershel Parker, "The Chaotic Legacy of the New Criticism and the Fair Augury of the New Scholarship," in Ruined Eden of the Present: Hawthorne, Melville, and Poe, ed. G. R. Thompson and Vergil Lokke (West Lafayette, Ind.: Purdue University Press, 1981), pp. 27-45.

5. M. H. Abrams, A Glossary of Literary Terms, 3d ed. (New York: Holt, Rinehart and Winston, 1971 ), p. 148.

6. Stanley Fish, "Literature in the Reader: Affective Stylistics," in Is There a Test in This Class?, p. 27. 


\section{Reader-Response Criticism and Teaching Composition}

the text requires the reader to perform: judging, questioning, finding answers, assuming perspectives, solving puzzles, and so on. Or as Iser writes: we "look forward, we look back, we decide, we change our decisions, we form expectations, we are shocked by their nonfulfillment, we question, we muse, we accept, we reject; this is the dynamic process of recreation" in reading. ${ }^{7}$ By describing these actions, reader-response critics discard the Affective Fallacy and join the New Scholars in rejecting the chief proscriptions of American New Criticism.

Whereas the old New Critical paradigm was hostile to any synthesis of rhetoric and poetics, the new paradigm that views literature as a temporal act of communication provides much encouragement for a rapprochement between literary criticism and composition theory. Like textual-biographical critics, composition theorists stress the importance of viewing the composing process as a series of acts by the writer. ${ }^{8}$ And like readerresponse critics, these rhetoricians suggest paying considerable attention to the reader while writing and analyzing discourse. ${ }^{9}$ These shared concerns and perspectives should encourage more exchanges between current rhetoric and poetics, exchanges that will benefit both disciplines and English studies as a whole.

A simple view of the composing process based on the traditional rhetorical categories-invention, arrangement, and style-will further illustrate the fit between composition theory

7. Wolfgang Iser, The Implied Reader (Baltimore: Johns Hopkins University Press, 1974), p. 288.

8. See Janet Emig, The Composing Process of Twelfth Graders (Urbana, Ill.: NCTE, 1971); and the survey of "Invention and Conceptions of the Composing Process" in Richard Young, "Invention: A Topographical Survey," in Teaching Composition: Io Bibliographical Essays, ed. Gary Tate (Fort Worth: Texas Christian University Press, 1976), pp. 33-40.

9. See, for example, W. Ross Winterowd, The Contemporary Writer (New York: Harcourt Brace Jovanovich, 1975), p. 3o; William F. Irmscher, The Holt Guide to English, 2d ed. (New York: Holt, Rinehart and Winston, 1976), pp. 172 ff.; Ruth Mitchell and Mary Taylor, "The Integrating Perspective: An Audience-Response Model for Writing," College English, 41 (1979), 247-71; Fred R. Pfister and Joanne F. Petrick, "A Heuristic Model for Creating a Writer's Audience," and Russell C. Long, "Writer-Audience Relationships: Analysis or Invention?" College Composition and Communication, 31 (1980), 213-20 and 221 26; and Jim Corder, "Rhetorical Analyses of Writing," in Tate, pp. 223-40, passim. 


\section{Appendix}

and recent literary criticism (primarily reader-response approaches). In what follows I will oversimplify the composing process and fall into such heresies as implying a form-content split. My point, however, is simply to provide a clear framework for examining some additional parallels between literary criticism and composition.

The goal of the composition teacher is to give the student writer alternative choices at every stage of the composing process. For example, in the area of invention (the generation of subject matter), the student has at least two alternatives: brainstorming and heuristics. Brainstorming is an unsystematic way of asking questions about a topic, while heuristics are systematic ways of asking questions. ${ }^{10}$ Literary critics often use heuristics in their analyses of literature, and such "critical" heuristics can be employed in teaching composition. For instance, Fish's heuristic "is simply the rigorous and disinterested asking of the question, what does this word, phrase, sentence, paragraph, chapter, novel, play, poem $d o$ ?"11 The student writer can use this same question to generate comments about any piece of discourse, including his or her own essays. An even more powerful heuristic can be found in the critical method of Kenneth Burke (whose writings have found an admiring audience among recent literary critics). Students can easily use the terms of Burke's Pentad-act, agent, agency, scene, and purpose-to generate questions about any human action. ${ }^{12}$ Clearly, then, literary criticism can provide resources for the composition teacher at the stage of invention.

Once subject matter is generated, what choices of form are available to the student? Again, literary theory provides some useful models for the composition teacher. To Burke, form is "the psychology of the audience"; it is "an arousing and fulfillment of desires. A work has form in so far as one part of it leads a reader to anticipate another part, to be gratified by the se-

10. See Winterowd, Contemporary Writer, p. 82.

11. Fish, "Literature in the Reader," pp. 26-27.

12. See Winterowd, Contemporary Writer, pp. 82-9o; Irmscher, pp. 3o-4o; and Young, pp. 13-16. Also cf. Kenneth Burke, "Questions and Answers about the Pentad," College Composition and Communication, 29 (1978), 330-35. 
quence." 13 In its emphasis on the reader and temporal sequence, Fish's "structure of the reader's experience" is similar to Burke's theory of form. ${ }^{14}$ Fish describes the specific ways the author arranges his reader's activities, what acts the reader "is being moved to perform" and the order in which he is moved to perform them. ${ }^{15}$ At the level of arrangement, a temporal readeroriented criticism encourages the composition teacher to make student writers aware of the expectations they set up in their essays and sensitive to their own ordering of the reader's responses.

The level of style provides another area where literary and composition theory interact. Again, the notion of choice can serve as our central concept: what sentence structures are available to the student writer? Two kinds of stylistics are relevant here, pedagogical and aesthetic. "Pedagogical stylistics, as the term implies, deals with teaching students to develop style," for example, using sentence-combining exercises; aesthetic stylistics refers to the study of style within literature. ${ }^{16}$ When we view style as choice, pedagogical stylistics becomes a matter of providing students with syntactic alternatives. Aesthetic stylistics, on the other hand, becomes a method of analyzing a text in terms of alternative choices among available structures. Empirical studies have shown that pedagogical stylistics can improve a student's syntactic fluency, his or her ability to combine syntactic units into more complex forms. ${ }^{17}$ No such strong claims are made for aesthetic stylistics. However, some aspects of aesthetic stylistics do have contributions to make to composition.

13. Kenneth Burke, Counter-Statement, 2d ed (1953; rpt. Berkeley: University of California Press, 1968), pp. 31, 124. See Richard E. Young, Alton L. Becker, and Kenneth L. Pike, Rhetoric: Discovery and Change (New York: Harcourt, Brace, and World, 1970), p. 323 .

14. But see the contrast drawn above in Ch. 3, pp. 69-7o.

15. Stanley E. Fish, "What Is Stylistics and Why Are They Saying Such Terrible Things About It?" in Is There a Text in This Class?, p. $9^{2}$.

16. W. Ross Winterowd, Contemporary Rhetoric: A Conceptual Background with Readings (New York: Harcourt Brace Jovanovich, 1975), p. 17. For a persuasive critique of many approaches to aesthetic stylistics, see Fish, "What Is Stylistics?" pp. 69-96; also see his "What Is Stylistics and Why Are They Saying Such Terrible Things About It?-Part II," boundary 2, 8 (1979), rpt. in Is There a Text in This Class?, pp. $247-67$.

17. See Frank O'Hare, Sentence-Combining: Improving Student Writing without Formal Grammar Instruction (Urbana, 1ll.: NCTE, 1973). 
Appendix

Take the following example from one of the most informed composition texts now available:

As we shall see, a major problem in student writing is the tendency not to put separate ideas together via the syntactic devices of the language. Here is a beginning paragraph from a freshman essay:

71 My greatest love is the love of my possessions. I feel like a king when I am amongst my possessions. But my possessions are not material possessions such as a beautiful new automobile or an enormous new house. Rather, my possessions are the wonders of nature: the beautiful, snow-capped mountains and the deep, crystal-clear lakes.

I think most readers would say that 71 is either immature or awkward or both. One alternative to it is the following:

72 I feel like a king when I am amongst the wonders of nature, for they are my greatest love and my greatest possessions: snow-capped mountains and deep, crystal-clear lakes rather than material things such as a new automobile or an enormous house.

I would argue that $7^{2}$ sounds more mature, perhaps even more intelligent, than 71 , and yet the idea content of both of them is essentially the same. ${ }^{18}$

Winterowd's purpose here is to illustrate the usefulness of pedagogical stylistics (in this case, embedding propositions within propositions). As he further argues: "The reason that most readers would prefer 72 over 71 is simply that in 72 the grammatical possibilities of the language have been used to put closely related ideas together in the neat syntactic package of a sentence."

By focusing on the syntactic choices, however, Winterowd ignores larger rhetorical strategies. If we examine $7_{1}$ and $7_{2}$ from the perspective of reader-response criticism, a form of aesthetic stylistics, we see that the structure of the reader's experience is radically different in each case. Though 71 may sound syntactically "immature," it is certainly more rhetorically "sophisticated" than 72 . In $7^{1}$ the freshman writer (consciously or not) has withheld the specific name of his "greatest love." After the first sen-

18. Winterowd, Contemporary Writer, pp. $3^{\circ} 8-\mathrm{og}$. 


\section{Reader-Response Criticism and Teaching Composition}

tence, the reader naturally jumps to the conclusion that "possessions" refer to material things. The second sentence offers nothing to contradict such a conclusion; it suggests the image of a king in his treasure room. (I distinctly remember my impression at this point during my first reading: not only does this student lack syntactic fluency but, more important, his values are clearly superficial and undeveloped.) The contrastive but begins the rhetorical reversal. The third sentence contradicts the reader's previous conclusion: the writer's greatest love is not material possessions. The final sentence not only provides a new equation (possessions $=$ nature), but it also forces the reader to repudiate his previous condescending attitude toward the writer's value system. Such a reversal makes a rather commonplace statement into a rhetorically forceful corrective. Winterowd's "more mature" rewrite of 71 manifests none of these rhetorical strategies: because no information is withheld, the reader jumps to no false conclusions and makes no mistaken judgments about the writer. Does 72 have more embedded propositions than 71 ? Yes. Is it more rhetorically sophisticated? No. ${ }^{19}$

In terms of their controlling paradigms and in view of shared models for invention, arrangement, and style, rhetoric and poetics are becoming more closely related in current theory and practice. This statement implies a theoretical justification for a historical point I made at the beginning of this Appendix: literary criticism and composition theory can be parts of one homogeneous discipline of English. Indeed, literature specialists have the potential to be the best qualified teachers of composition. But I would like to stress a further point. Not just any English professor can teach writing, even if he or she has accepted the model of literature as communicative act. It is clear that compostion teachers are becoming specialists within the English Department (not just second-class citizens). There is now a growing empirical and rhetorical body of knowledge that all

19. Brook Thomas provides further arguments for the use of readerresponse criticism in the teaching of writing--see his "Re-Reading, Re-Writing," CEA Forum, 11, No. 3 (1981), 1-6. 


\section{Appendix}

serious teachers of composition must master. ${ }^{20}$ Nevertheless, as I have tried to show, composition and literary study need not be antithetical functions within our discipline. A synthesis of rhetoric and poetics will go a long way toward curing the English Department's split personality.

20. See Tate's collection of bibliographical essays cited in $n .8$ above. 